\title{
PENGEMBANGAN SENSE OF HUMOR DAN PENGARUHNYA PADA EMOSI ANAK
}

\author{
Nunung Suryana Jamin \\ Dosen PAUD Universitas Negeri Gorontalo \\ nunung@ung.ac.id
}

Received: 25 November 2019; Revised: 29 November 2019; Accepted: 7 Desember 2019

\begin{abstract}
ABSTRAK
Permasalahan emosi yang tidak terkontrol pada anak-anak masa kini menjadi masalah serius yang tidak boleh dianggap ringan oleh guru maupun orang tua. Lingkungan yang cepat berubah dan teknologi yang seharusya memudahkan aktivitas anak disisi lain malah memberikan dampak negatif pada sisi emosi anak. Tujuan kajian pustaka ini untuk memberikan gambaran pengembangan sense of humor pada anak dan bagaimana pengaruhnya terhadap emosi anak. Sense of humor tidak hanya dimiliki oleh orang dewasa, tetapi juga dimiliki oleh anak-anak. Rasa cemas, takut, dan stres yang dialami anak akibat tekanan dan harapan orang tua dan guru yang berlebihan membuat humor bisa jadi sarana bantuan katarsis emosi anak. Sense of humor yang baik membuat anak diliputi keceriaan dan suasana hati bahagia. Hal ini mendorong perkembangan emosi anak jadi lebih seimbang. Pengembangan sense of humor anak dapat dilatih melalui permainan badut-badutan, permainan kata-kata lucu, dan permainan kekanak-kanakan. Ada empat upaya orang tua dan guru dalam mengembangkan sense of humor anak, yaitu: (1) menjadi model humor; (2) perhatikan serius humor dari anak; (3) ajarkan anak bahwa orang dewasa juga bisa lebih lucu lagi; (4) Menciptakan lingkungan yang kaya humor.
\end{abstract}

Kata kunci: sense of humor, emosi.

\section{PENDAHULUAN}

Dunia anak adalah dunia keceriaan, kegembiraan, dan kesenangan. Segala tingkah laku, suara, dan mimik anak menimbulkan tawa dan keriyangan tersendiri bagi siapa saja yang ada didekatnya. Pola tingkah laku anak yang lucu, polos, dan apa adanya selalu bisa menghibur sekaligus memberikan rasa kegembiraan pada orang tua, kerabat, guru dan teman-temannya, maupun bagi anak itu sendiri. Naluri untuk mencari kegembiraan ini, sebenarnya pada manusia sudah merupakan kebutuhan yang melekat sejak bayi, dan terus berkembang bersama hingga manusia itu dewasa (Hendarto dalam Rahmanadji, 2007: 213). Rangsangan dari lingkungan keluarga, sekolah, dan masyarakatlah yang menentukan sejauhmana kebutuhan anak akan kegembiraan ini bisa terpenuhi.

Kegembiraan anak biasanya bisa dipenuhi melalui hiburan atau hal-hal lucu yang disebut dengan humor. Rasa gembira anak bisa berasal dari dirinya sendiri, orang tua, guru atau teman-temannya. Orang tua atau guru bisa saja meniru suara atau bunyi binatang, bertingkah aneh dan nyentrik, atau bernyanyi dengan lagu yang kata-katanya sudah diubah menjadi unik dan lucu. Partisipasi aktif dari anak tentu bisa lebih merangsang anak untuk merasa lucu, gembira, dan terhibur. Secara normal manusia butuh hiburan untuk ketahanan diri dalam proses pertahanan hidupnya kelak (Setiawan 
dalam Rahmanadji, 2007: 213). Ketahanan diri yang kuat tentu akan mendukung perkembangan emosi anak secara optimal.

Humor merupakan salah satu sarana hiburan pada manusia, tak terkecuali anakanak. Selain untuk ketahanan diri, sense of humor yang dimiliki anak sangat penting untuk membantu mengembangkan kreativitas, berpikir divergen, imajinatif, menumbuhkan kepercayaan diri, memperluas pertemanan serta terhindar dari stres (Nugraha dan Rachmawaty, 2004: 9.4). Ketika anak terhindar dari stres diharapkan emosi anak akan berkembang secara wajar dan alami. Anak yang memiliki sense of humor yang baik akan mudah mendapatkan mood atau suasana hati yang baik pula, selanjutnya akan dapat menciptakan lingkungan sosial di rumah maupun di sekolah yang nyaman, tentram, dan menyenangkan.

Dalam kehidupan sehari-hari, baik di rumah maupun di sekolah, anak mengalami berbagai macam tekanan, bisa dari orang tua, keluarga, guru maupun teman-temannya. Padatnya pelajaran di sekolah, persaingan dengan teman bermain serta upaya memenuhi harapan orang tua bisa menjadi masalah tersendiri buat anak. Stres, cemas, dan tertekan mewarnai dinamika emosi anak sehari-hari (www.fabrianschool.com).

Pada usia sekolah permasalahan emosi berupa stress, cemas, dan tertekan sering muncul (Patmonodewo, 2003: 32). Salah satu upaya untuk mengatasi masalah emosi diatas adalah melalui pengembangan sense of humor (Hurlock, 2000: 235). Karena semua orang memiliki sense of humor termasuk anak-anak, maka diperlukan latihan dan stimulus dari lingkungan untuk optimalisasi perkembangan kecerdasan dan kepribadiannya (www.fabrianschool.com). Dengan sense of humor, anak akan terlatih memandang dunia dengan energi positif dan penuh keceriaan sejak usia belia dan sanggup melewati dinamika kehidupan yang sarat dengan berbagai emosi negatif ini dengan senyum optimis.

\section{PEMBAHASAN}

Humor merupakan fenomena dalam kehidupan manusia pada umumnya, menyangkut hubungan dan interaksi sesamanya. Humor bahkan sudah ada sejak manusia itu ada di muka bumi ini. Istilah humor itu sendiri tidak berakar pada kebudayaan dan peradaban bangsa Indonesia (Suprana, 2013: 3). Perkembangan humor telah mengalami metamorfosis dan dialektika sepanjang zaman, dari zaman Yunani kuno, zaman Romawi kuno, zaman renaissance sampai dengan zaman sekarang. Tetapi humor itu sendiri tidak mudah untuk didefinikan.

Humor menurut Immanual kant (dalam Suprana, 2013: 8) mendefinisikan humor adalah sesuatu yang merangsang perubahan mendadak dari rasa penuh harapan menjadi nihil. Sedangkan humor menurut Seligmen dan Petersen (2004: 585) diartikan sebagai fenomena yang lucu, termasuk didalamnya kemampuan untuk melihat, menginterpretasi, menikmati, menciptakan serta menyampaikan hal-hal yang tidak lazim pada umumnya.

Sejalan dengan pendapat Seligmen dan Petersen, Sarlito pada Seminar Nasional Humor di Semarang (1996) mengatakan bahwa humor adalah segala sesuatu (keadaan, perkataan, dan perbuatan) yang bisa menimbulkan kesan lucu sehingga memancing reaksi tertawa (dalam Sulaiman, 2007: 26). Humor ini bisa dilakukan sengaja seperti dalam profesi pelawak atau dilakukan tidak sengaja seperti cicak jatuh dari langit-langit kamar. 
Adapun penyebab seseorang tertawa atau tersenyum berbeda tiap orang. Menurut Plato dan Aristoteles (dalam Suyasa, 2014:1), penyebab orang tertawa adalah perasaan superiority terhadap individu lain atau tertawa karena keadaan negatif yang menimpa orang lain. Sedangkan menurut Martin (dalam Suyasa, 2014: 1) seseorang bisa saja tertawa disebabkan hal-hal positif yang menimpa orang lain. Selain itu orang tertawa juga dipengaruhi oleh banyak faktor, diantaranya kepribadian, budaya, dan masa lalu orang tersebut (Scarlett, 2005: 94).

Dibandingkan dengan teori humor pada orang dewasa, teori humor pada anakanak hanya terdapat beberapa saja, salah satunya teori Freud. Menurut Freud (dalam Benson dan Haith, 2009: 193 dan Klein, 2003: 18) ada tiga tahapan dalam pengembangan humor pada anak-anak, yaitu:

1. Tahap bermain (usia 2 - 3 tahun)

2. Tahap yang diikuti olok-olok (usia 4 - 6 tahun)

3. Tahap bercanda yang benar (usia 7 tahun)

Dalam pengembangan humor pada anak-anak, tahap olok-olok cuma berisi omong kosong atau merupakan suatu ekspresi anak yang mirip dengan komik tertentu, dan tidak bermaksud untuk menyampaikan makna. Unsur cerita pada komik tidak terlalu penting dibanding gambarnya (Hurlock, 2000: 337). Olok-olok merupakan hasil penemuan orang dewasa pada anak-anak dengan mencari (memilih) alasan yang bersifat absurd atau konyol. Anak sangat menikmati membuat suatu kekonyolan. Dan olok-olok bagi anak suatu kebutuhan untuk didengar dan diperhatikan.

Untuk tahap becanda, anak memerlukan cara yang dapat diterima secara sosial untuk mengekspresikan perasaan dan makna yang tidak dapat dinyatakan atau diungkapkan. Pada tahap becanda yang dilihat adalah ekspresi, biasanya ekspresi lebih pada perbedaan individu, sosial, kelompok, dan konsep stereotipe. Selanjutnya Freud melihat tahap bermain merupakan asal mula dari tahap olok-olok dan bercanda, dimana anak diumpamakan sebagai bagian dari suatu negara atau kelompok sosial (Klein, 2003: 19).

Tahapan pengembangan humor anak selanjutnya dikembangkan oleh Paul McGhee pada tahun 1979 kemudian direvisi tahun 2002. Tahapan pengembangan humor Paul McGhee ini didasarkan pada tahapan kognitif dari Piaget, dimana jenis humor anak ini cenderung tertarik pada perubahan yang mendasar dalam kemampuannya untuk memahami dunia (Scarlett, 2005: 105).

Tahapan-tahapan pengembangan humor anak menurut McGhee (Scarlett, 2005: 105 - 106) terdiri dari:

Tahap 0: Tertawa tanpa humor

Tahap ini merupakan tahap pra-humor "stadium 0", jadi meskipun tanpa humor anak dapat menunjukan senyum dan tertawa.

Tahap 1: Tertawa dengan figur tambahan.

Pada tahap ini, anak menunjukan adanyapeningkatan kesadaran lingkungan antar pribadi dan turut berpartisipasi dalam humor sosial dengan orang tua atau figur tambahan lainnya melalui permainan seperti cilukba. Permainan ini mengusung konsep bahwa objek itu permanen meski tidak terlihat. Ini menyangkut aspek kognitif yang akan berkembang ke aspek emosi bayi. Interaksi dengan orangtua saat melakukan 
permainan ini juga bermanfaat untuk mengenalkan intonasi suara dan kata-kata baru. Selain juga, bayi belajar urutan, misalnya orangtua setelah menutup muka lalu membukanya sambil berseru, "Baaa...." Aktivitas ini akan membuatnya gembira dan merasa dekat dengan orang tua (www.tabloid-nakita.com) .

Tahap 2: Memperlakukan suatu obyek secara berbeda

Pada tahap 2, anak mulai memproduksi "Lelucon" nonverbal dengan melakukan tindakan aneh seperti meletakkan mangkuk pada kepalanya sendiri atau berpura-pura bicara dengan sepatunya.

Tahap 3: Ada kesalahan dalam penamaan obyek atau perilaku

Setelah kosa kata anak menuju pada titik kritis, dia bisa melanjutkan humor tentang keganjilannya, kemudian dia juga salah dalam penyebutan objek atau tindakan. Dan menurut McGhee bahwa anak-anak pada tahap ini sering menikmati memanggil hal-hal dengan nama yang berlawanan, misalnya dingin mereka sebut panas, lalu lakilaki disebut gadis.

Tahap 4: Bermain dengan kata-kata

Kompetensi lisan anak tumbuh, dimana dia kurang tergantung pada obyek sebagai sumber humor. Anak mungkin bereksperimen dengan irama kata-kata yang dibuat konyol dan permainan lucu lainnya yang tidak secara langsung memiliki hubungan dengan obyek dalam jangkauannya.

Tahap 5: Teka-teki dan lelucon

Saat anak berkembang, dia mulai memahami humor yang memiliki makna bahwa sesuatu lelucon yang tidak masuk akal harus bisa dijelaskan anak untuk menjadi sesuatu yang masuk akal. Dia mulai sering menghafal teka-teki dan lelucon, dan menggunakannya sebagai sarana untuk memulai interaksi sosial dengan teman sebaya dan orang dewasa.

Masih dengan asumsi dasar dari teori Piaget, Paul McGhee dalam pengembangan humor anak membagi empat tahap keganjilan dalam humor anak (Klein, 2003: 19 - 20), yaitu:

1. Tindakan yang ganjil, dimulai dari usia1 - 2 tahun

2. Keganjilan bahasa, dimulai 2 tahun

3. Keganjilan konseptual, dimulai 4 tahun

4. Bermain kata, yang bermakna lebih, dimulai 7 tahun. Diusia ini anak akan mengoreksi keganjilan tersebut

Tahap-tahap perkembangan humor anak diatas secara ringkas dapat dilihat dalam bentuk-bentuk umum humor anak menurut Hurlock (2000: 21), yaitu:

1. Permainan kata-kata dengan memutar balik arti atau pengucapannya

2. Gambar karikatur orang atau hewan yang melakukan hal-hal lucu.

3. Menirukan ucapan nyanyian, tingkah lau atau tindakan orang atau binatang

4. Lelucon dan cerita porno terutama mengenai hal-hal yang bersifat tabu, misalnya seks atau orang yang berwenang

5. Salah ucap, seringkali dengan sengaja

6. Berakrobat atau melakukan hal-hal tolol

7. Berpakaian macam-macam agar berpenampilan aneh

8. Membadut atau "melucu"

9. Degelan atau "berolok-olok" dengan teman sebaya 
10. Lelucon yang berusaha memojokkan seseorang ke posisi yang sulit

11. Sarkasme atau karikatur verbal tentang orang lain

Baik tahapan pengembangan humor anak dari Mc Ghee maupun Freud menjelaskan adanya perkembangan humor pada anak, bisa mendorong perkembangan bahasa, kognitif, dan sosial emosi anak. Humor juga membantu anak mengatur perasaan yang sulit seperti ketakutan, kemarahan serta dorongan untuk menjadi agresif (Scarlett, 2005: 108).

Untuk bisa menikmati humor seseorang haruslah memiliki sense of humor. Menurut Martin dkk. (dalam Rumondor, 2007: 18) sense of humor adalah cara pandang dan berinteraksi dengan dunia melalui filter berupa hiburan, tawa dan keceriaan. Sedangkan Freud (dalam Sulaiman, 2007: 29) menguraikan sense of humor merupakan proses defensive mechanism yang membuat individu mengatasi masalah-masalahnya tanpa mengalamai emosi negatif dengan cara melihat masalah tersebut dengan perspektif lain.

Sense of humor dapat berupa kemampuan seseorang dalam menangkap makna lucu dari suatu hal (gejala, kejadian, ucapan dan sebagainya), termasuk suatu hal menyangkut diri sendiri (Sarwono, 2005: 16). Sense of humor juga membantu seseorang dalam melihat dan memahami ketidaksesuaian dalam humor, termasuk perasaan seseorang ketika menghadapi hal-hal yang lucu kemudian mengekspresikan dengan tertawa atau tersenyum (Mc Ghee dalam Sulaiman, 2007: 30).

Beberapa pendekatan sense of humor lebih menekankan pada pentingnya faktor emosional daripada kognitif. Misalnya Leventhal dan Safer (dalam Ruch, 1998: 6) melihat sense of humor yang bermakna dikonseptualisasikan sebagai faktor perbedaan individu dalam pengalaman emosional dan ekspresi yang dimiliki. Ciri seseorang memiliki sense of humor bisa dilhat dari kecenderungan untuk mempertahankan keceriaan, suasana hati yang bahagia dan memilki waktu luang yang banyak. Untuk itu menurut Leventahal dan Safer bahwa teori sense of humor harus lebih memperhatikan secara luas teori emosi dalam rangka mengembangkan hubungan kedua teori tersebut.

Sense of humor secara umum lebih menimbulkan respon afektif (mood, perasaan, dan sikap) dibanding respon kognitif (Thorson and Powell, 1993: 799). Respon kognitif biasanya ada pada lelucon. Humor juga memiliki hubungan dengan mood, dimana pengaruhnya bisa dilihat pada perubahan perilaku anak yang dipengaruhi oleh jenis humor, usia/tahap perubahan dan lingkungan terkait (Ruch 1998: 330). Dimana anak dengan sense of humor yang baik akan merasa lebih bahagia dan lebih optimis, memiliki harga diri yang tinggi, dan dapat menangani perbedaan (mereka sendiri dan orang lain) dengan baik (kidshealth.org).

Sense of humor menurut Martin (2003: 5) merupakan konsep yang multidimensional yang terdiri dari enam aspek, yaitu

1. Kemampuan membuat humor, menghibur orang lain, mendapatkan lelucon, dan mengingat lelucon.

2. Temperamental trait, habitual cheerfulness.

3. Respon estetis, dapat menikmati materi humor jenis tertentu

4. Sikap, sikap positif terhadap humor, jadi orang yang humoris

5. Sudut pandang yang luas, pandangan kagum terhadap kehidupan

6. Coping strategy, kecenderungan untuk mempertahankan perspektif humor walau menghadapi kesulitan. 
Aspek sense of humor menurut Svehak (dalam Martin, 2003: 8) adalah sebagai berikut: (1) Metamessage sensitivitas atau kemampuan untuk mengenali humor dalam suatu situasi; (2) Menyukai Humor atau menikmati humor dan peran sebagai humoris; (3) Ekspresi emosional atau kecenderungan untuk bebas mengekspresikan emosi seseorang. Sedangkan menurut Thorson \& Powell (Hostetler dalam Jose dkk. 2007:598) aspek sense of humor dilihat dalam empat dimensi, yaitu: (1) Humor production (menciptakan humor), terang-terangan penggunaan humor digunakan dalam situasi sosial; (2) Coping humor, mencoba melihat sisi yang lucu dari berbagai hal; (3) Humor appreciation (mengapresiasi humor), menyukai humor; dan (4) Humor attitude (Sikap terhadap humor), menyetujui humor.

Aspek-aspek sense of humor diatas bisa menjadi indikator untuk melihat apakah seseorang memiliki sense of humor atau tidak. Untuk anak-anak, indikator sense of humor disesuaikan dengan usia dalam tahapan pengembangan humor anak. Misalnya Menurut Herlina Liem (Psikolog dari LPT UI), anak memasuki usia 3 hingga 5 tahun mulai paham ungkapan verbal yang bisa dianggapnya sebagai sesuatu yang lucu. Kini anak tidak lagi tertawa karena adanya keganjilan fisik (mulai usia 2 tahun, termasuk tahap primitif), tetapi adanya keanehan pada konsep. Seperti, ketika ia melihat anak seusianya minum dengan dot, ia tidak tertawa. Tapi, saat melihat ayahnya minum dengan dot, anak bisa menertawakannya. Selanjutnya humor anak pun akan terus beranjak ke tahap berikutnya, sejalan dengan perkembangan kemampuan bahasa dan kognitifnya (lifestyle.okezone.com).

Manfaat sense of humor bagi perkembangan anak (www.fabrianschool.com), adalah:

1. Humor dapat meningkatkan kecerdasan anak. Louis Franzini dalam bukunya Kids Who Laugh, How to Develop Your Child's Sense of Humor menyatakan bahwa humor pada anak-anak berhubungan langsung dengan kecerdasan, kreativitas, kemampuan sosial, empati, rasa percaya diri, penghargaan atas diri sendiri dan kemampuan memecahkan masalah yang lebih sulit. Kecerdasan yang diamksud ialah kecerdasan emosional serta intelektualnya.

2. Humor dapat mengeratkan ikatan batin antara anak dengan orang tuanya, serta meningkatkan hubungan antarsesama.

3. Humor dapat meningkatkan kekebalan tubuh anak, sehingga dapat menjaga kestabilan kesehatan mental dan fisiknya, serta membantu mencegah masuknya berbagai penyakit.

4. Humor dapat meningkatkan fungsi perkembangan anak. Dengan humor anak akan lebih mampu mengekspresikan kemampuan berpikir dan kreativitasnya yang sedang tumbuh.

Besarnya manfaat yang didapat dari pengembangan sense of humor anak, mendorong orang tua maupun guru untuk melakukan berbagai upaya agar sense of humor anak berkembang baik sejalan dengan perkembangan emosi anak. Ada beberapa upaya yang bisa dilakukan orang tua maupun guru dalam mengembangkan sense of humor anak (kidshealth.org), adalah:

1. Menjadi model humor. Salah satu hal terbaik yang bisa dilakukan dalam mengembangkan sense of humor anak adalah diri sendiri (bisa guru atau orang tua, kerabat). Dengan diri sendiri yang menjadi model akan membangun hubungan 
emosional yang kuat, suasana yang hangat dan mood yang baik untuk perkembangan emosi anak yang sehat.

2. Perhatikan serius humor dari anak. Mendorong upaya anak untuk bisa mengembangkan humor, apakah itu dari membaca (berpotensi tidak lucu) lelucon dari buku, menggambar sesuatu yang lucu atau bertingkah laku aneh. Pujilah atas usaha tersebut dan tertawalah bersama karena tertawa merupakan salah satu kesenangan hidup.

3. Ajarkan anak bahwa orang dewasa juga bisa lebih lucu lagi. Hal ini akan membuat anak bisa berbagi pengamatan atau reaksi yang lucu disetiap saat.

4. Menciptakan lingkungan yang kaya humor. Kelilingi anak dengan buku-buku yang lucu, termasuk buku gambar atau sajak yang konyol, komik. televisi, film, dan situs web yang bisa dinikmati semua umur.

Sense of humor dapat dilatih sejak dini melalui permainan badut-badutan, permainan kata-kata lucu, dan permainan kekanak-kanakan. Pengembangan sense of humor ini sangat erat kaitannya dengan dengan cara berpikir fleksibel. Sense of humor tidak dapat berkembangan bila cara berpikir seseorang serius, tegang, dan kaku (Nugraha dan Rachmawati, 2004: 9.4).

\section{SIMPULAN}

Sense of humor dimiliki semua orang, baik orang dewasa maupun anak-anak. Sense of humor dibutuhkan untuk menikmati humor dengan santai dan penuh keceriaan sehingga perkembangan anak, khususnya perkembangan emosi berlangsung optimal. Pengembangan sense of humor anak dapat dilatih melalui permainan badut-badutan, permainan kata-kata lucu, dan permainan kekanak-kanakan.

Beberapa upaya Orang tua maupun guru dalam mengembangkan sense of humor anak, adalah (1) Menjadi model humor; (2) Perhatikan serius humor dari anak; (3) Ajarkan anak bahwa orang dewasa juga bisa lebih lucu lagi; (4) Menciptakan lingkungan yang kaya humor. Dari berbagai permaianan serta upaya guru maupun orang tua diatas, diharapkan bisa menciptakan perasaan dan mood yang baik bagi anak, selanjutnya emosi anak akan berkembangan secara wajar.

\section{DAFTARA PUSTAKA}

Benson, Janette, B. dan Haith, Marshall, M. (ed.). 2009. Social and Emotional Development in Infancy and Early Childhood, USA San diego: Elsevier

Hurlock, Elizabeth, B. 2000. Perkembangan Anak. Jilid 1 dan Jilid 2. Jakarta: Erlangga

Jose, Helena. Pedro, Parreira. Thorson, James, A. dan Alwardt, Debra. 2007. A FactorAnalytic Study of the Multidimensional Sense of Humor Scale with a Portuguese Sample. North American Journal of Psychology. Vol. 9. No. 3. 595-610

Klein, Amelia, J. (ed.). 2003. Humor In Childrens Lives, A Guidebook Practioners. USA: Praeger Publisher

Martin, Rod, A. 2003. Running Head: Sense of Humor. London. Ontario. Canada. University of Western Ontario. http://www.humoursummerschool.org/01/ articlesNhandouts/PosPsych.pdf. Diakses tanggal 16 November 2014

Nugraha, Ali, dan Rachmawati, Yeni. 2004. Metode Pengembangan Sosial Emosional. Jakarta: Universitas Terbuka 
Patmonodewo, Soemiarti. 2003. Pendidikan Anak Prasekolah. Jakarta: Rineka Cipta Rahmanadji, Didiek, 2007. Sejarah, Teori, Jenis, dan Fungsi Humor, Jurnal: Bahasa, Sastra, Seni dan Pengajarannya. Univeristas Negeri Malang. Agustus. Volume 35, Nomor2. Hal. 213-221

Ruch, Willibald. (ed.). 1998. The Sense of Humor Exploration of a Personality Characteristic. Berlin: Mouton de Gruyter

Rumondor, Pingkan, C. B. 2007. Hubungan Dimensi Humor Styles Dengan Stres Pada Mahasiswa Tahun Pertama. Skripsi Tidak Dipublikasikan. Jakarta: Fakultas Psikologis. Universitas Indonesia

Sarwono, Sarlito, W. 2005. Psikologi Dalam Praktek. Jakarta: Restu Agung

Scarlett, W. George. Naudeau, Sophie. Salonius-Pasternak, Dorothy, dan Ponte, Iris. 2005. Children's play. USA: Sage Publication, Inc. http://www.sagepub.com/ upm-data/4884_ScarlettChapter5.pdf, Diakses tanggal 19 November 2014.

Seligman, Martin. E. P. dan Peterson, Christopher. 2004. Character Strengths and virtues. New York: Oxford University Press

Sulaiman. 2007. Hubungan Antara Sense of Humor Dengan Kebermaknaan Hidup Pada Masyarakat Betawi. Skripsi Tidak Dipublikasikan. Jakarta: Fakultas Psikologi. Universitas Islam Negeri Syarif Hidayatullah

Suprana, Jaya. 2013. Humorologi. Jakarta: PT. Elex Media Komputindo

Thorson, James, A. dan Powell, F. C. 1993. Sense of Humor and Dimensions of Personality. Journal of Clinical Psychology, November. Vol. 49. No. 6. Hal. 799-809

Suyasa, P. Tommy, Y. S, 2014. Identifikasi Jenis Humor:Lucu, Lucu, dan Lucu. Conference Paper: Temu Ilmiah Nasional Psikologi, di Jakarta, Volume: 1 Tarumanagara University. http://s2psikologi.tarumanagara.ac.id/wpcontent/ uploads/2010/09/41-identifikasi-jenis-humor lucu-lucu-dan-lucup-tommy-y-s-suyasa.pdf. Diakses tanggal 16 November 2014

Lyness, D'Arcy. Februari 2012. Encouraging Your Child's Sense of Humor. http://kidshealth.org/ parent/growth/learning/child_humor.html, Diakses tanggal 26 November 2014

Permana, Bambang. Kamis. 29 April 2010. Manfaat Humor Untuk Perkembangan Anak. http://www.fabrianschool.com/berita-147--manfaat-humor-untukperkem bangan-anak--sekolah-depok.html. Diakses tanggal 26 November 2014

Permainan untuk bayi usia 6-9 bulan. http://www.tabloid-nakita.com/read/2884/ permainan-untuk-bayi-usia-6-9-bulan, Diakses tanggal 22 November 2014.

Tertawa 500 kali sehari bikin sehat \& Cerdas!. Jumat, 29 Januari 2010. http://lifestyle.okezone. com/read/2010/01/29/27/298976/27. Diakses tanggal 26 November 2014 